\title{
Effects of Seasonal Thermal Stratification on Nitrogen Transformation and Diffusion at the Sediment-Water Interface in a Deep Canyon Artificial Reservoir of Wujiang River Basin
}

\author{
Yongmei Hou ${ }^{1,2}$, Xiaolong Liu ${ }^{1, *}$, Sainan Chen ${ }^{3}$, Jie Ren ${ }^{1,2}$, Li Bai ${ }^{1}$, Jun Li ${ }^{1}$, Yongbo Gu ${ }^{1,2}$ and Lai Wei ${ }^{1,2}$ \\ 1 Tianjin Key Laboratory of Water Resources and Environment, Tianjin Normal University, \\ Tianjin 300387, China; ymhou20@163.com (Y.H.); renjie@tjnu.edu.cn (J.R.); baili@tjnu.edu.cn (L.B.); \\ lijun5931@163.com (J.L.); guyongbo@tjnu.edu.cn (Y.G.); weilai@tjnu.edu.cn (L.W.) \\ 2 School of Geography and Environmental Science, Tianjin Normal University, Tianjin 300387, China \\ 3 Institute of Surface-Earth System Science, Tianjin University, Tianjin 300072, China; sainanchen@tju.edu.cn \\ * Correspondence: Xiaolong.liu@tjnu.edu.cn
}

Citation: Hou, Y.; Liu, X.; Chen, S.; Ren, J.; Bai, L.; Li, J.; Gu, Y.; Wei, L. Effects of Seasonal Thermal Stratification on Nitrogen Transformation and Diffusion at the Sediment-Water Interface in a Deep Canyon Artificial Reservoir of Wujiang River Basin. Water 2021, 13, 3194. https://doi.org/10.3390/ w13223194

Academic Editor:

Bommanna Krishnappan

Received: 20 September 2021

Accepted: 9 November 2021

Published: 11 November 2021

Publisher's Note: MDPI stays neutral with regard to jurisdictional claims in published maps and institutional affiliations.

Copyright: (c) 2021 by the authors Licensee MDPI, Basel, Switzerland. This article is an open access article distributed under the terms and conditions of the Creative Commons Attribution (CC BY) license (https:// creativecommons.org/licenses/by/ $4.0 /)$.

\begin{abstract}
Watershed-scale nitrogen pollution in aquatic systems has become a worldwide concern due to its continuous impact on water quality deterioration, while the knowledge of key influencing factors dominating nitrogen transportation and transformation at the sediment-water interface (SWI) remains limited, especially in impounded rivers with an artificial reservoir. Hence, for a better understanding of the effects of thermal stratification on nitrogen transformation, we investigated the nitrogen species and isotopes in the sediment of a deep reservoir in Southwest China. Our results confirmed a significant difference in nitrogen species and isotopic composition in sediment between those in the thermal stratification period and non-thermal stratification period and indicated that the sediment biogeochemical process and transportation were clearly linked to the variations in water temperature and dissolved oxygen dominated by the process of thermal stratification. Significant seasonal differences in $\mathrm{NH}_{4}{ }^{+}-\mathrm{N}$ and $\mathrm{NO}_{3}{ }^{-}-\mathrm{N}$ in pore water of the upper layer $(0-19 \mathrm{~cm})$ revealed that nitrification exhausted $\mathrm{NH}_{4}{ }^{+}$in the non-stratified period (NSP), and a potential low mineralization rate appeared when compared with those in the stratified period (SP). Seasonal differences in nitrogen species and isotope fractionation of $\delta^{15} \mathrm{~N}-\mathrm{PON}$ (about $2.3 \%$ in SP) in the upper layer sediment indicated a higher anaerobic mineralization rate of organic matter in SP than that in NSP. The diffusion fluxes of $\mathrm{NH}_{4}{ }^{+}-\mathrm{N}$ at SWI were 9.48 and $15.66 \mathrm{mg} \cdot \mathrm{m}^{-2} \cdot \mathrm{d}^{-1}$ in NSP and $\mathrm{SP}$, respectively, and annual $\mathrm{NH}_{4}{ }^{+}-\mathrm{N}$ diffusion accounted for $21.8 \%$ of total storage in the reservoir. This study demonstrated that the nitrogen cycling processes, especially nitrification, denitrification, and mineralization, have been largely altered along with the changes in dissolved oxygen and that the diffusion of nitrogen species varied with the presence of the oxygen. The results contribute to the future study of watershed nitrogen budget evaluation and suggest that the endogenous nitrogen released from the sediment-water interface should be emphasized when aiming to fulfil water management policies in deep reservoirs.
\end{abstract}

Keywords: thermal stratification; nitrogen transformation; sediment-water interface; reservoir; $\mathrm{NH}_{4}{ }^{+}$diffusion

\section{Introduction}

Excessive nitrogen loading at watershed-scale in aquatic systems, with the constant input of anthropogenically sourced active nitrogen, has posed serious environmental problems, such as eutrophication, greenhouse gas emission, and water quality deterioration $[1,2]$. Watershed-scale nitrogen pollution persistently attracts worldwide concern attributed to the enormous challenge of nitrogen assessment and management in global ecosystems. By intercepting runoff and sediment, massive dams and reservoirs worldwide would deposit the dissolved and adsorbed nutrients with the sediment and conserved 
within the reservoir, which tends to reduce levels of nutrient transportation to downstream rivers and instead accumulate the nutrients in the reservoir [3,4]. Moreover, recent studies have emphasized that the accumulation of nitrogen in aquatic systems was affected by external nitrogen input as well as internal nitrogen release, which is dominated by nitrogen biogeochemical processes [5,6]. Evaluating the transformation and transportation of nitrogen species among the sediment-water interface (SWI) is essential if we aim to reduce nitrogen pollution in a reservoir and help to establish relevant policies for reservoir water quality protection. However, few studies have assessed the contribution of nitrogen releasing from the SWI in the reservoir. Currently, an increasing number of studies have raised the controversies surrounding the role of sediment in nitrogen transportation and transformation at the SWI, as well as its influence on the fate and distribution of nitrogen afterwards, which has become a hot topic in academic community $[7,8]$.

Nitrogen experiences complex biogeochemical processes under different environmental conditions, e.g., DO has been recognized as the crucial factor that dominates nitrification and denitrification, and dissimilatory nitrate reduction to anammox (DNRA) generally occurs in sediment with a high $\mathrm{C} / \mathrm{N}$ ratio and $\mathrm{C}$ loading [9]. Generally, ammonification, denitrification, and DNRA were regarded as being the dominant processes in a hypoxic environment in the stratified period (SP), while ammonification and nitrification could be favored by oxygenated conditions in the non-stratified period (NSP). In recent decades, intensive demands for hydropower resources led to the emergence of special landscape features caused by the cascading development in most rivers [10,11], which significantly posed a challenge for the synchronously high-efficiency management of water resources and the water environment. Over the past 60 years, approximately 58,000 large reservoirs have been built worldwide [12], which altered the original ecosystem conditions and attracted widespread concern [13].

It was well known that there was seasonal thermal stratification in deep canyon reservoirs, and water temperatures in the hypolimnion of deep lakes/reservoirs were generally low $\left(4-6^{\circ} \mathrm{C}\right)$ and remained nearly constant $[13,14]$. However, temperaturedriven hypoxia in the stratified period (SP) and oxygenated hypolimnion in the nonstratified period (NSP) may dominate the nitrogen exchange between sediment and water. Muller et al. [15] indicated that, in a lake, anaerobic environmental conditions were more conducive to internal nitrogen release than those in aerobic conditions. In addition, some studies reported that $\mathrm{T}$ and $\mathrm{DO}$ were the key factors controlling endogenous nitrogen diffusion of sediment in a shallow lake and that the diffusion fluxes of $\mathrm{NH}_{4}{ }^{+}$were positively correlated with T, while there was a negative correlation with DO [16]. Cai et al. [17] investigated the relationship between nitrogen species and biological activities in shadow lake sediment, and reported that T and DO significantly alter the abundance of bacterial genes and community structures, subsequently affecting the transformation processes of sediment nitrogen. Hence, in this study, we hypothesized that the seasonal variation in DO and $\mathrm{T}$ would dominate the nitrogen transformation at SWI in a deep reservoir. However, as noted above, most current studies focused on nitrogen diffusion and influencing factors in thermal stratified lakes, while few studies have conducted targeted research in deep canyon reservoirs, especially the deep reservoirs in Southwest China. Because an artificial reservoir has a special hydrological regulation and water management regime for the purpose of power generation, the particulate matter sources and accumulation rates into the sediment are different from those in lakes. In order to optimize water protection and reduce nitrogen accumulation in reservoirs, sediment nitrogen transformation and diffusion to overlying water-which tends to play a role in endogenous pollution-urgently needed to be understood.

Water-soluble inorganic nitrogen and adsorbed inorganic nitrogen were the dominant nitrogen forms at the SWI; a growing number of studies have documented that the water-soluble and adsorbed nitrogen varied significantly along with the water chemistry changes [18]. Generally, there are two methods that have been employed universally to study nitrogen cycling at the SWI: incubation of intact sediment core experiments and 
profiling of pore waters coupled to deterministic models $[19,20]$. The former methodology has revealed that the nitrogen species fluxes at the SWI varied among different aquatic environments, but it is difficult to infer the detailed relevant transformation processes involved at different depths of sediment. For the purpose of both identifying the nitrogen cycling processes and estimating the effluxes and influxes of nitrogen species at the SWI, the later methodology could provide more information on the nitrogen fate at the SWI. Additionally, stable isotopes approaches have been applied extensively in recent studies on watershed-scale nitrogen cycling for better understanding of the nitrogen transformation processes [21-23] and for identifying the source of particulate matter.

Most current studies on nitrogen transformation and diffusion of sediment paid close attention to aquatic systems, such as rivers, lakes, and oceans, while the knowledge on the fate of nitrogen and related key influencing factors at the sediment and water interface in deep reservoirs is still limited. In order to understand the effects of seasonal thermal stratification on nitrogen transformation and to quantitatively evaluate the contamination of endogenous nitrogen in a deep reservoir, the concentrations of nitrogen species and stable isotopes $\left(\delta^{15} \mathrm{~N}-\mathrm{PON}\right)$ of particulate organic matter were analyzed in sediments, which were collected during SP and NSP in Wujiangdu (WJD) reservoir, a typical deep canyon eutrophic reservoir in Southwest China. The study aimed to (1) clarify the seasonal variation characteristics of sediment nitrogen species in a deep reservoir; (2) to understand how the DO affected the transformation and diffusion of sediment nitrogen by comparative study between SP and NSP; (3) to quantitatively estimate the nitrogen exchanges at the SWI and assess the influence of seasonal thermal stratification. The results of this study provide implications useful for assessing the effects of endogenous nitrogen on nitrogen contamination in a deep reservoir that has characteristics of seasonal thermal stratification and nitrogen transformation and transportation that are similar to other deep reservoirs worldwide, and helping to fulfill water management policies in watersheds in consideration of the nitrogen contamination originating from the SWI.

\section{Materials and Methods}

\subsection{Study Area}

Wujiang River Basin is one of the largest tributaries on the south bank of the Yangtze River, and the WJD reservoir is the earliest (1979) seasonal regulating hydropower station built and put into use in China. The WJD reservoir is located in the middle reaches of the Wujiang River Basin $\left(106^{\circ} 47^{\prime}\right.$ E, $27^{\circ} 18^{\prime}$ N $\left., 27,790 \mathrm{~km}^{2}\right)$, which drains the Southeast Asian Karst Region [24,25]. The average annual flow rate of the WJD reservoir is $502 \mathrm{~m}^{3} \cdot \mathrm{s}^{-1}$, and the storage area is $47.8 \mathrm{~km}^{2}$. There are abundant coal resources and industrial production bases in the area, such as a Wujiang manganese steel plant, phosphate fertilizer plant, and chemical fertilizer plant. Historically, intensive human activity has caused a serious eutrophication in the WJD reservoir, mainly on account of perennial cage fish aquaculture; hence, the hydrochemistry of the WJD reservoir is characterized by its high nitrogen loading [5].

The WJD reservoir, a deep canyon artificial reservoir, had significant seasonal variation in the profiles of water chemical parameters (especially the water T and DO). The WJD reservoir becomes thermally non-stratified from November to March, while remaining thermally stratified from April to October [5]. The water $\mathrm{T}$ difference between upper and lower layers reaches to $12.4^{\circ} \mathrm{C}$ during the $\mathrm{SP}$, while the water profile is homogeneous in the NSP, with small temperature differences $\left(0.11^{\circ} \mathrm{C}\right)$ among the vertical water mass. In Spring (typically in April) and Autumn (in October), the water layers are in a transitional stage of thermal stratification, and the most significant thermally stratification and nonstratification occurs in July and January, respectively. Thus, it was ideal to study the influences of seasonal thermal stratification on nitrogen transformation and transportation in the sediment-water interface by comparing those in July and January. The sediment type in the WJD reservoir is fine-grained, with a high proportion of clay [26]. The water chemical parameters in the WJD reservoir are shown in Table 1. 
Table 1. Water chemical parameters in the WJD reservoir from our previous study [27].

\begin{tabular}{|c|c|c|c|c|c|}
\hline & $\mathrm{T}\left({ }^{\circ} \mathrm{C}\right)$ & $\mathrm{DO}\left(\mathrm{mg} \cdot \mathrm{L}^{-1}\right)$ & $\mathrm{EC}\left(\mathrm{ms} \cdot \mathrm{cm}^{-1}\right)$ & $\mathrm{pH}$ & $\mathrm{NH} 4^{+}-\mathrm{N}\left(\mathrm{mg} \cdot \mathrm{L}^{-1}\right)$ \\
\hline \multirow[t]{2}{*}{ Range } & $10.7 \sim 28.6$ & $6.6 \sim 15.9$ & $0.18 \sim 0.32$ & $7.8 \sim 8.9$ & $0.01 \sim 1.44$ \\
\hline & $\mathrm{K}^{+}\left(\mathrm{mg} \cdot \mathrm{L}^{-1}\right)$ & $\mathrm{Na}^{+}\left(\mathrm{mg} \cdot \mathrm{L}^{-1}\right)$ & $\mathrm{Ca}^{2+}\left(\mathrm{mg} \cdot \mathrm{L}^{-1}\right)$ & $\mathrm{Mg}^{2+}\left(\mathrm{mg} \cdot \mathrm{L}^{-1}\right)$ & $\mathrm{NO}_{3}^{-}-\mathrm{N}\left(\mathrm{mg} \cdot \mathrm{L}^{-1}\right)$ \\
\hline Range & $1.56 \sim 1.81$ & $3.36 \sim 4.38$ & $61.32 \sim 65.64$ & $10.78 \sim 11.80$ & $1.23 \sim 3.50$ \\
\hline
\end{tabular}

\subsection{Sampling and Analysis}

A sampling site was chosen at the front of the dam $(<1 \mathrm{~km}$ to the dam $)$ in Wujiangdu Reservoir, where the depth of the water reached to $113 \mathrm{~m}$ and $95 \mathrm{~m}$ in the NSP and SP, respectively. Based on previous studies that indicated that sediment cores in lakes and reservoirs are generally consistent, single or two sediment cores would thus be enough for studying the transformation and spatial distribution of nutrients and heavy metals in a lake or reservoir [28-31]. Moreover, this study focused on nitrogen transformation and transportation mainly in the deepest parts of the reservoir (close to the dam), where the area was relatively small and the sediment was consistent. Referring to previous studies [28-31], two sampling campaigns were conducted on the NSP (January 2018) and SP (July 2019), respectively, and two sediment cores were collected by a sediment corer (Hydro-Bios, Inc., Altenholz, Germany) at the front of dam in the reservoir ( $<1 \mathrm{~km}$ from the dam), which is the deepest site in the reservoir (Figure 1). The sediment core collected in the NSP was $58 \mathrm{~cm}$ long and that in SP was $52 \mathrm{~cm}$; the diameter of the sampling tube was $7 \mathrm{~cm}$. Sample cores were sliced and sub-sampled immediately after sampling in the field (the first $20 \mathrm{~cm}$ was sliced at a $1 \mathrm{~cm}$ depth interval and at $2 \mathrm{~cm}$ intervals afterwards), then stored in anaerobic sample tubes, as in the studies of Hogarh et al. and Copetti et al. [28,31]. These samples were centrifuged by a centrifugal machine placed in a $\mathrm{N}_{2}$-filled container to separate pore water and were then filtered with a $0.45 \mu \mathrm{m}$ cellulose acetate membrane. After these pretreatment process, they were stored at $4{ }^{\circ} \mathrm{C}$ away from light. In the laboratory, after the centrifuged sediment samples were freeze-dried at $-30{ }^{\circ} \mathrm{C}$, they were ground with an agate mortar, passed through a 100-mesh sieve, and then stored in polyethylene bags under $4{ }^{\circ} \mathrm{C}$ till analyzed. The overlying waters were sampled by two methods. First, for the overlying water close to the sediment (depth $<50 \mathrm{~cm}$ ), we collected the water samples using a silicone tube (diameter 6 inches) by siphon method in the sediment corer before sediment subsampling; second, the overlying water samples above the sediment $(>1 \mathrm{~m})$ were sampled with a water sampler (Hydro-Bios, Altenholz, Germany).

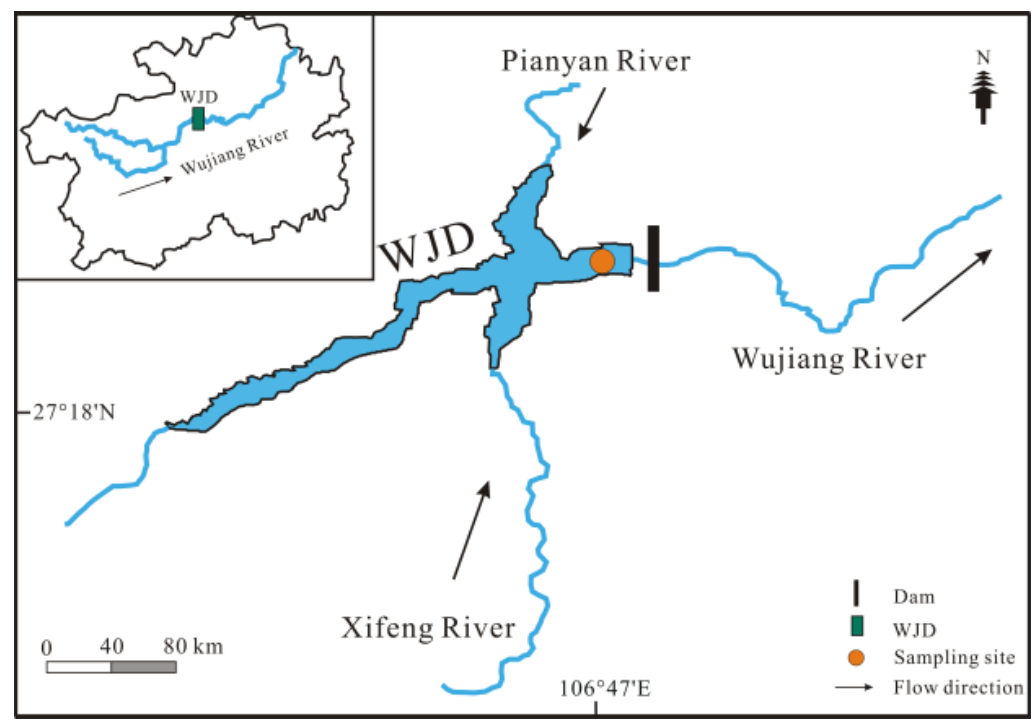

Figure 1. Map showing the study area and the sampling sites at the WJD reservoir. 
Water-soluble nitrogen was extracted from $2 \mathrm{~g}$ of the ground sediment samples using $10 \mathrm{~mL}$ deionized water, then $10 \mathrm{~mL} 2 \mathrm{~mol} \cdot \mathrm{L}^{-1} \mathrm{KCl}$ was added and processed with the same method to obtain the absorbed inorganic nitrogen - the potential nitrogen of which could be replaced by special iron. Then, the concentrations of nitrogen species $\left(\mathrm{NH}_{4}{ }^{+}-\mathrm{N}, \mathrm{NO}_{3}{ }^{-}-\mathrm{N}\right.$, and total nitrogen, TN) of pore waters and water-soluble and absorbed nitrogen species were determined by continuous-flow analysis (AA3 Auto Analyzer, SEAL, Norderstedt, Germany). The nitrogen detection limit was $0.001,0.003,0.003$, and $0.01 \mathrm{mg} \cdot \mathrm{L}^{-1}$ for $\mathrm{NO}_{2}{ }^{-} \mathrm{N}, \mathrm{NO}_{3}{ }^{-}-\mathrm{N}, \mathrm{NH}_{4}{ }^{+}-\mathrm{N}$, and $\mathrm{TN}$, respectively. $\mathrm{NO}_{2}{ }^{-}-\mathrm{N}$ was under the detection limit. Laboratory standards and replicated samples were employed to keep the precision of $\mathrm{NH}_{4}{ }^{+}, \mathrm{NO}_{3}{ }^{-}$, and $\mathrm{TN}$ concentration analysis higher than $\pm 5 \%$. The dissolved organic nitrogen (DON) had a differential value to TN and total inorganic nitrogen (TIN, including $\mathrm{NH}_{4}{ }^{+}-\mathrm{N}$ and $\mathrm{NO}_{3}{ }^{-}-\mathrm{N}$ ).

Processed sediment samples were weighed at $0.5 \mathrm{~g}$ and $15 \mathrm{~mL} 0.5 \mathrm{~mol} \cdot \mathrm{L}^{-1} \mathrm{HCl}$ and $2 \mathrm{~mol} \cdot \mathrm{L}^{-1} \mathrm{KCl}$ solution was added to remove inorganic carbon and nitrogen, then samples were washed repeatedly with deionized water until becoming neutral. The samples were freeze-dried and ground afterwards for nitrogen-stable isotopes $\left(\delta^{15} \mathrm{~N}-\mathrm{PON}\right)$ and $\mathrm{C} / \mathrm{N}$ molar ratio analysis by stable isotopic mass spectrometer (MAT-253) and elemental analyzer (Elementar, Rhine main, Germany) at Tianjin Normal University.

\subsection{Calculation of Nitrogen Diffusion at SWI}

The diffusion of water-soluble nitrogen at the SWI was driven by the nitrogen gradients and calculated by Fick's first law, following equation [19,20]

$$
\mathrm{F}=\mathrm{D}_{\mathrm{S}} \times \varphi \times(\partial \mathrm{c} / \partial \mathrm{z})
$$

where $\mathrm{F}\left(\mathrm{mg} \cdot \mathrm{m}^{-2} \cdot \mathrm{d}^{-1}\right)$ is the diffusion flux of nitrogen, and $\partial \mathrm{c} / \partial \mathrm{z}\left(\mathrm{mg} \cdot \mathrm{L}^{-1} \cdot \mathrm{cm}^{-1}\right)$ is the gradient of dissolved substance across the SWI, which could be fitted by exponential function using the nutrient concentration of overlying water and the depth of SWI of about $5 \mathrm{~cm}$. Then, the derivative of exponential function when $Z=0$ was taken as the concentration gradient. $C\left(\mathrm{mg} \cdot \mathrm{L}^{-1}\right)$ was the concentration of nitrogen, and $Z(\mathrm{~cm})$ was the vertical distance, which started from the upper boundary of the SWI and increased with depth. $\varphi$ is the surface sediment porosity and can be approximately estimated by following equation [32]:

$$
\varphi=(\mathrm{r}-\mathrm{s}) / \mathrm{r}
$$

where $r$ is the wet weight of sediment, while $s$ is the dry weight. $D_{S}\left(\mathrm{~cm}^{2} \cdot \mathrm{s}^{-1}\right)$ is the actual diffusion coefficient under different $\mathrm{T}$ conditions, which can be expressed as follows $[32,33]$ :

$$
\begin{gathered}
D_{S}=\varphi D_{0}(\varphi<0.7) \\
D_{S}=\varphi^{2} D_{0}(\varphi \geq 0.7)
\end{gathered}
$$

where $\mathrm{D}_{0}$ is the diffusion coefficient in infinite dilution, and the values for $\mathrm{NO}_{3}{ }^{-} \mathrm{N}$ and $\mathrm{NH}_{4}{ }^{+}-\mathrm{N}$ at $25^{\circ} \mathrm{C}$ are $19.0 \times 10^{-6}$ and $19.8 \times 10^{-6} \mathrm{~cm}^{2} \cdot \mathrm{s}^{-1}$, respectively. Thus, it could be corrected according to the following formula due to the different $\mathrm{T}$ [34]:

$$
\begin{aligned}
& \mathrm{D}_{0}\left(\mathrm{NO}_{3}{ }^{-}-\mathrm{N}\right)=19.0 \times 10^{-6}+0.4 \times\left(\mathrm{T}-25^{\circ} \mathrm{C}\right) \\
& \mathrm{D}_{0}\left(\mathrm{NH}_{4}{ }^{+}-\mathrm{N}\right)=19.8 \times 10^{-6}+0.4 \times\left(\mathrm{T}-25^{\circ} \mathrm{C}\right)
\end{aligned}
$$

\subsection{Data Processing}

IBM SPSS Statistics 19 was used for data analysis. Analysis of variance (ANOVA) was performed to examine the differences in the nitrogen concentrations in the SP and NSP. Additionally, $t$-tests were used to identify the variables of the $\mathrm{C} / \mathrm{N}$ ratio and $\delta^{15} \mathrm{~N}-\mathrm{PON}$ in sediments of before and after artificial dam construction. Significance levels were reported to be $p<0.05$ and $p<0.001$. Microsoft Excel was used to analyze the linear correlation 
of variables and obtain the value of the correlation coefficient $\left(R^{2}\right)$. All the data were completed by Origin 2018, Grapher 15, and Microsoft Office 2010. The concentrations of nitrogen species in the sediment of the WJD reservoir are listed in Table 2.

Table 2. The concentrations of nitrogen species in sediment of WJD reservoir.

\begin{tabular}{|c|c|c|c|c|c|c|c|}
\hline $\begin{array}{c}\text { Sampling } \\
\text { Period }\end{array}$ & Types & $\begin{array}{l}\text { Nitrogen } \\
\text { Species }\end{array}$ & $\begin{array}{c}\text { Min } \\
\left(\mathrm{mg} \cdot \mathrm{kg}^{-1}\right)\end{array}$ & $\begin{array}{c}\mathrm{Max} \\
\left(\mathrm{mg} \cdot \mathrm{kg}^{-1}\right)\end{array}$ & $\begin{array}{c}\text { Average } \\
\left(\mathrm{mg} \cdot \mathrm{kg}^{-1}\right)\end{array}$ & SD & $\begin{array}{c}\text { Coefficientof } \\
\text { Variation }\end{array}$ \\
\hline \multirow{5}{*}{ SP } & water-soluble & $\mathrm{NH}_{4}^{+}-\mathrm{N}$ & 12.15 & 31.37 & 21.01 & 5.12 & 0.24 \\
\hline & nitrogen & $\mathrm{TN}$ & 63.51 & 121.36 & 86.83 & 14.34 & 0.17 \\
\hline & \multirow{3}{*}{$\begin{array}{l}\text { absorbed } \\
\text { nitrogen }\end{array}$} & $\mathrm{NH}_{4}^{+}-\mathrm{N}$ & 58.07 & 85.71 & 70.99 & 7.65 & 0.11 \\
\hline & & $\mathrm{NO}_{3}{ }^{-}-\mathrm{N}$ & 4.81 & 12.70 & 7.16 & 2.28 & 0.32 \\
\hline & & $\mathrm{TN}$ & 90.95 & 255.65 & 159.20 & 45.35 & 0.28 \\
\hline \multirow{6}{*}{ NSP } & \multirow{3}{*}{$\begin{array}{l}\text { water-soluble } \\
\text { nitrogen }\end{array}$} & $\mathrm{NH}_{4}^{+}-\mathrm{N}$ & 5.74 & 27.64 & 14.86 & 4.44 & 0.30 \\
\hline & & $\mathrm{NO}_{3}{ }^{-}-\mathrm{N}$ & 0.06 & 0.58 & 0.31 & 0.14 & 0.46 \\
\hline & & $\mathrm{TN}$ & 57.39 & 339.36 & 144.49 & 62.43 & 0.43 \\
\hline & \multirow{3}{*}{$\begin{array}{c}\text { absorbed } \\
\text { nitrogen }\end{array}$} & $\mathrm{NH}_{4}^{+}-\mathrm{N}$ & 48.04 & 89.97 & 71.93 & 9.75 & 0.14 \\
\hline & & $\mathrm{NO}_{3}{ }^{-}-\mathrm{N}$ & 5.78 & 24.75 & 12.67 & 4.75 & 0.37 \\
\hline & & $\mathrm{TN}$ & 120.68 & 398.65 & 223.85 & 63.77 & 0.28 \\
\hline
\end{tabular}

\section{Results}

\subsection{Seasonal Variation of Inorganic Nitrogen in Sediment Pore Water}

The concentrations of $\mathrm{NH}_{4}{ }^{+}-\mathrm{N}$ in pore water ranged from 5.7 to $27.6 \mathrm{mg} \cdot \mathrm{L}^{-1}$ and from 15.3 to $31.4 \mathrm{mg} \cdot \mathrm{L}^{-1}$ (averaged 14.9 and $21.0 \mathrm{mg} \cdot \mathrm{L}^{-1}$ ) in the NSP and SP (Table 2), respectively. There were significant seasonal differences in vertical distribution of $\mathrm{NH}_{4}^{+}$ and $\mathrm{NO}_{3}{ }^{-}$in the upper layer $(0-19 \mathrm{~cm})$ of the sediment between the two periods, but the distribution nearly synchronously varied at deep layers $(>19 \mathrm{~cm}$ ) (Figure 2). The concentrations of $\mathrm{NH}_{4}{ }^{+}-\mathrm{N}$ were lower in the upper layer of the sediment, then increased with depth in the NSP, while reversing in the SP. Inorganic nitrogen in pore water was mainly composed of $\mathrm{NH}_{4}{ }^{+}-\mathrm{N}$, accounting for $90.8 \sim 99.7 \%$ in the NSP. On the contrary, the concentration of $\mathrm{NO}_{3}{ }^{-}-\mathrm{N}$ in sediment pore water was only determined at 0-19 $\mathrm{cm}$ depth (the concentration ranged from 0.056 to $0.58 \mathrm{mg} \cdot \mathrm{L}^{-1}$ ) in the NSP, while it was under the detection limit $\left(0.001 \mathrm{mg} \cdot \mathrm{L}^{-1}\right)$ in the SP and the deep layer of the sediment in the $\mathrm{NSP} \mathrm{NO}_{3}{ }^{-} \mathrm{N}$ was detected only in the NSP at the depth of $0-19 \mathrm{~cm}$ with a low concentration in pore water, while the concentration of $\mathrm{NH}_{4}{ }^{+}-\mathrm{N}$ notably exceeded $\mathrm{NO}_{3}{ }^{-}-\mathrm{N}(p<0.001)$ in this period.

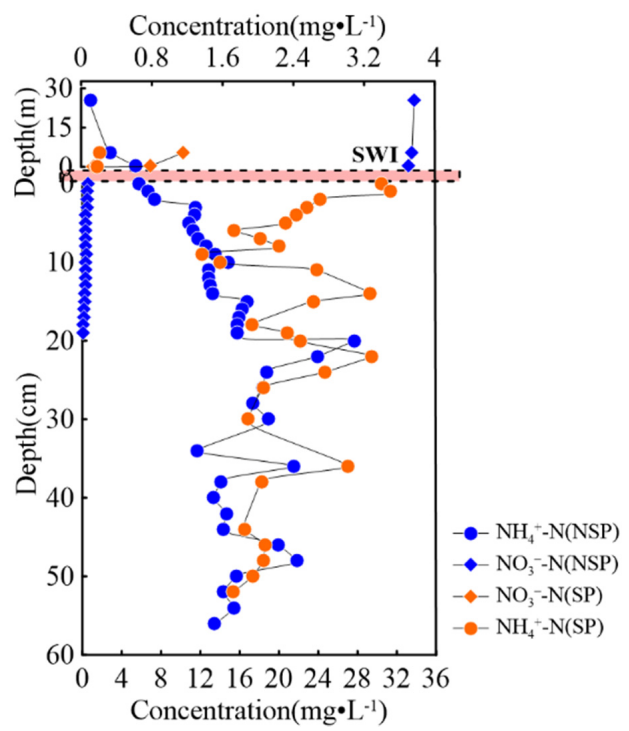

Figure 2. Characteristics of the vertical distribution of inorganic nitrogen in sediment pore water. 


\subsection{Seasonal Changes in Water-Soluble and Adsorbed Nitrogen in Sediment}

Concentrations of adsorbed total nitrogen (TN) ranged from 120.7 to $398.56 \mathrm{mg} \cdot \mathrm{kg}^{-1}$ in the NSP and from 91 to $255.7 \mathrm{mg} \cdot \mathrm{kg}^{-1}$ in the SP, with an average value of 233.9 and $159.2 \mathrm{mg} \cdot \mathrm{kg}^{-1}$, respectively. The water-soluble TN ranged from 57.4 to $339.4 \mathrm{mg} \cdot \mathrm{kg}^{-1}$ and from 63.5 to $121.36 \mathrm{mg} \cdot \mathrm{kg}^{-1}$ (averaged 144.5 and $86.8 \mathrm{mg} \cdot \mathrm{kg}^{-1}$ ) in the NSP and SP (Table 2), respectively. The adsorbed TN was 1.4 to 2.7 times higher than that of the water-soluble TN. Meanwhile, the concentrations of nitrogen species displayed different seasonal variation; adsorbed TN in the sediment at $0-10 \mathrm{~cm}$ in the SP increased with depth, and there was no significant change in water-soluble TN (Figure 3).

\section{Concentration $\left(\mathrm{mg} \cdot \mathrm{kg}^{-1}\right)$}
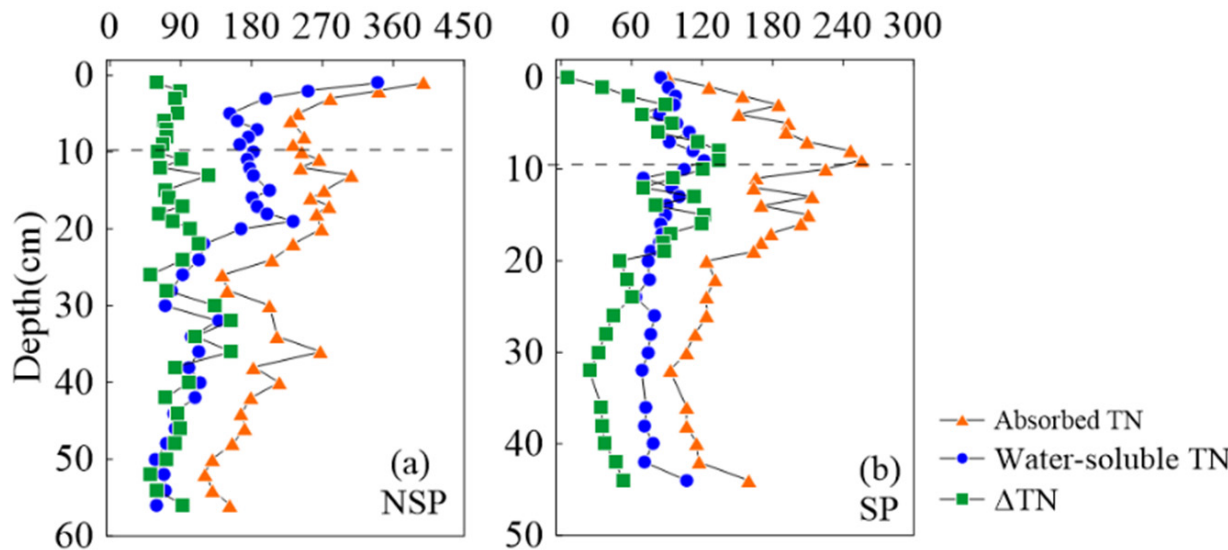

$0 \quad 90180270360450$

$0 \quad 60120180240300$
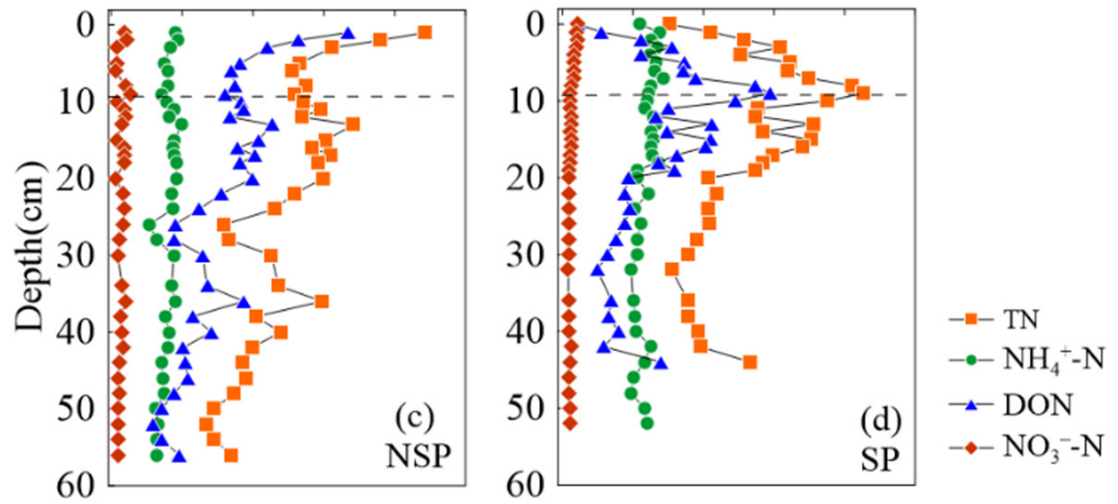

Figure 3. Characteristics of the vertical distribution of absorbed nitrogen species in sediment.

The vertical distribution of adsorbed TN in two seasons was roughly the same as those of DON, and there were obvious seasonal differences in the upper layer $(0-10 \mathrm{~cm})$ of sediment (Figure 3). In addition, DON concentrations were higher and decreased with depth in the NSP, while displaying the opposite in the SP (Figure 4). Figure 4 shows the vertical variation of different nitrogen species in both the SP and NSP, with the statistics of each nitrogen species including the whole data of the profile. Moreover, the concentration of adsorbed inorganic nitrogen varied in a smaller range than that in $\mathrm{DON}$, and $\mathrm{NH}_{4}{ }^{+}-\mathrm{N}$ was the main component, accounting for $80.5 \%$ to $93.3 \%$ of the TN. The concentrations of absorbed $\mathrm{NH}_{4}{ }^{+}-\mathrm{N}$ ranged from 48.0 to $90.1 \mathrm{mg} \cdot \mathrm{kg}^{-1}$ in the NSP and from 58.1 to $85.7 \mathrm{mg} \cdot \mathrm{kg}^{-1}$ in the SP, while the concentrations of absorbed $\mathrm{NO}_{3}{ }^{-}-\mathrm{N}$ ranged from 5.8 to $24.75 \mathrm{mg} \cdot \mathrm{kg}^{-1}$ in the NSP and from 4.8 to $12.7 \mathrm{mg} \cdot \mathrm{kg}^{-1}$ in the SP. DON was the dominant component of TN (Figure 4), ranging from 52.8 to $300.1 \mathrm{mg} \cdot \mathrm{kg}^{-1}$ in the NSP and from 13.0 to $176.4 \mathrm{mg} \cdot \mathrm{kg}^{-1}$ in the SP, with a mean proportion ranging from $47 \%$ to $60 \%$. 


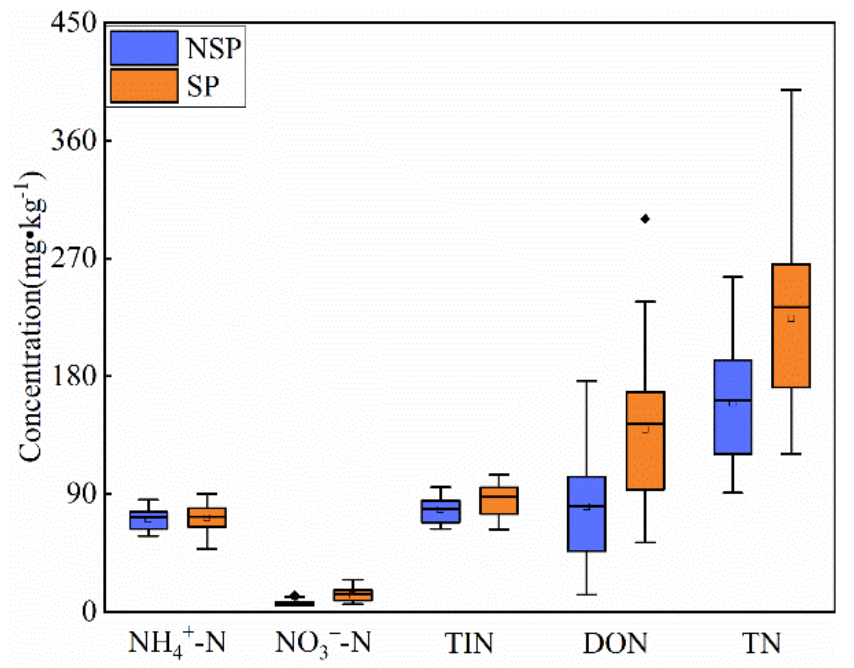

Figure 4. Concentrations of absorbed nitrogen species in the WJD reservoir.

3.3. Characteristics of the Vertical Distribution of Stable Nitrogen Isotope ( $\left.\delta^{15} N-P O N\right)$ and the C/N Ratio in Sediment Particulate Organic Matter

The profiles of the $\mathrm{C} / \mathrm{N}$ ratio displayed no obvious seasonal variation when increasing with depth (Figure 5), and the values varied from 9.1 to 16.2 (mean value was 11.8) in the NSP and from 10.1 to 15.3 (mean value was 12.2) in the SP. The $\delta^{15} \mathrm{~N}-\mathrm{PON}$ values ranged from $+5.7 \%$ o to $+6.8 \%$ ond from $+4.9 \%$ o to $+7.2 \%$, with an average value of $+6.3 \%$ and $+5.7 \%$ in the NSP and SP, respectively. Additionally, the $\delta^{15} \mathrm{~N}-\mathrm{PON}$ values decreased slightly when compared with those from 10 years ago (from $+6.84 \%$ o to $+13.64 \%$ o), and there was inconspicuous difference in the vertical distribution of $\delta^{15} \mathrm{~N}-\mathrm{PON}$ in the NSP. Contrarily, it was roughly divided into two stages in the SP: the first stage was 0-15 cm (the mean value was $+6.0 \%$, with the highest value of $+7.2 \%$ and the lowest value of $+4.9 \%$ ) and generally decreased with depth; the second stage was $16-52 \mathrm{~cm}$ (mean value was $+5.4 \%$ o , where the $\delta^{15} \mathrm{~N}$-PON varied in a small range.

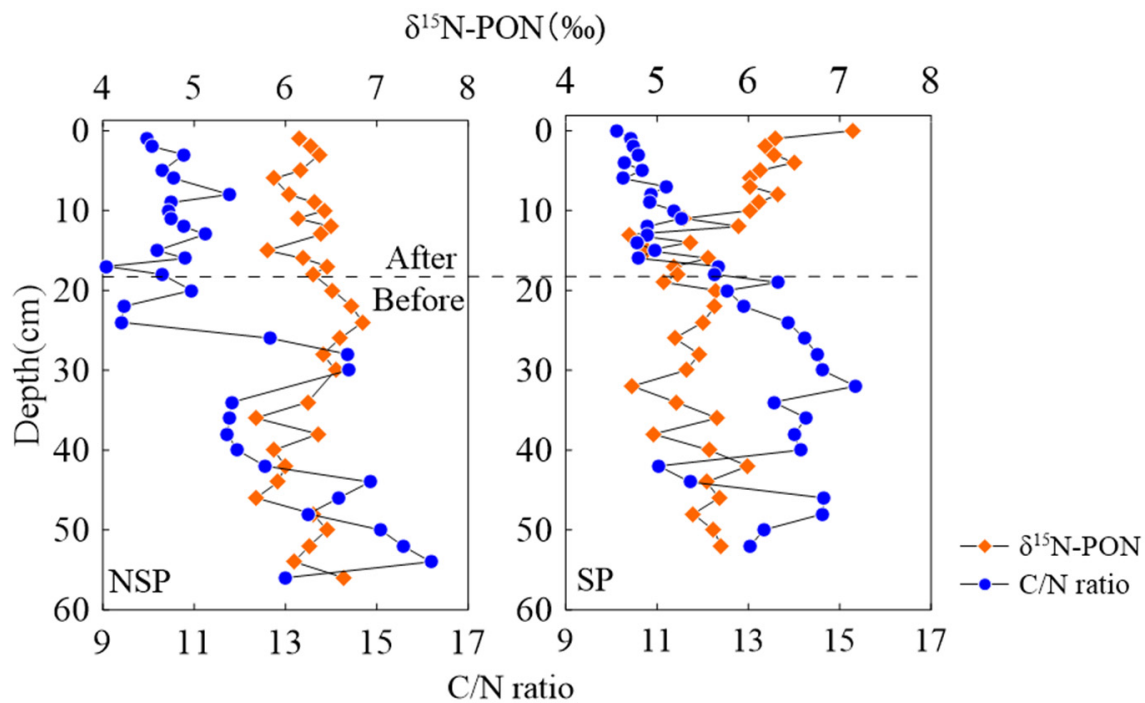

Figure 5. Characteristics of the vertical distribution of $\delta^{15} \mathrm{~N}-\mathrm{PON}$ and $\mathrm{C} / \mathrm{N}$ ratio in particulate organic matter.

\subsection{Diffusion Fluxes of Inorganic Nitrogen at the SWI}

Considering the seasonal differences in $\mathrm{DO}$ and $\mathrm{T}$ conditions in a deep reservoir, the actual $\mathrm{T}$ at SWI during the sampling period $\left(14.7^{\circ} \mathrm{C}\right.$ in the NSP and $12.2^{\circ} \mathrm{C}$ in the SP) was used to correct the actual diffusion coefficients of $\mathrm{NH}_{4}{ }^{+}-\mathrm{N}$ and $\mathrm{NO}_{3}{ }^{-}-\mathrm{N}$ (Table 3). The 
diffusion fluxes $(F)$ of inorganic nitrogen during the sampling period were calculated with $\partial \mathrm{c} \partial \mathrm{z}$ and $\varphi$ (Table 4), and the values for $\mathrm{NH}_{4}{ }^{+}-\mathrm{N}$ were 9.48 and $15.66 \mathrm{mg} \cdot \mathrm{m}^{-2} \cdot \mathrm{d}^{-1}$; for $\mathrm{NO}_{3}{ }^{-}-\mathrm{N}$ the values were -1.49 and $-0.21 \mathrm{mg} \cdot \mathrm{m}^{-2} \cdot \mathrm{d}^{-1}$ in the NSP and SP, respectively. Generally, a positive flux represents nitrogen released from sediment to overlying water, while a negative flux represents that from the overlying water to the sediment.

Table 3. The actual diffusion coefficient under different $\mathrm{T}$ conditions of $\mathrm{NH}_{4}{ }^{+}-\mathrm{N}$ and $\mathrm{NO}_{3}{ }^{-}-\mathrm{N}^{-}$

\begin{tabular}{ccc}
\hline $\mathbf{T}\left({ }^{\circ} \mathbf{C}\right)$ & $\mathbf{N H}_{\mathbf{4}}{ }^{+}-\mathbf{N}\left(\mathbf{c m}^{2} \cdot \mathbf{s}^{-\mathbf{1}}\right)$ & $\mathbf{N O}_{3}{ }^{-} \mathbf{- N}\left(\mathbf{c m}^{\mathbf{2}} \cdot \mathbf{s}^{-\mathbf{1}}\right)$ \\
\hline 0 & $9.8 \times 10^{-6}$ & $9.78 \times 10^{-6}$ \\
12.2 & $9.87 \times 10^{-6}$ & $9.33 \times 10^{-6}$ \\
14.7 & $10.54 \times 10^{-6}$ & $10.01 \times 10^{-6}$ \\
25 & $19.8 \times 10^{-6}$ & $19 \times 10^{-6}$ \\
\hline
\end{tabular}

Table 4. Calculation of inorganic nitrogen diffusion fluxes at the SWI of WJD.

\begin{tabular}{|c|c|c|c|c|c|c|}
\hline $\begin{array}{l}\text { Sampling } \\
\text { Time }\end{array}$ & $\begin{array}{l}\text { Inorganic } \\
\text { Nitrogen }\end{array}$ & $\begin{array}{l}\text { Exponential } \\
\text { Function }\end{array}$ & $\mathbf{R}^{2}$ & $\varphi$ & $\begin{array}{c}\partial \mathrm{d} \partial \mathrm{z} \\
\left(\mathrm{mg} \cdot \mathrm{L}^{-1} \cdot \mathrm{cm}^{-1}\right)\end{array}$ & $\begin{array}{c}F \\
\left(\mathrm{mg} \cdot \mathrm{m}^{-2} \cdot \mathrm{d}^{-1}\right)\end{array}$ \\
\hline January 2018 & $\mathrm{NH}_{4}{ }^{+}$ & $y=3.2791 e^{-0.368 x}$ & 0.88 & \multirow{4}{*}{0.82} & -1.27 & 9.48 \\
\hline January 2018 & $\mathrm{NO}_{3}^{-}$ & $y=0.838 e^{0.2492 x}$ & 0.92 & & 0.21 & -1.49 \\
\hline \multirow{2}{*}{ July 2019} & $\mathrm{NH}_{4}^{+}$ & $y=6.3376 e^{-0.353 x}$ & 0.73 & & -2.24 & 15.66 \\
\hline & $\mathrm{NO}_{3}^{-}$ & $y=0.24 e^{0.1345 x}$ & 0.63 & & 0.032 & -0.21 \\
\hline
\end{tabular}

\section{Discussion}

\subsection{Effects of Seasonal Thermal Stratification on Nitrogen Transformation in Sediment Pore Water}

In the sediment of the WJD reservoir, the variations in the concentrations of $\mathrm{NO}_{3}{ }^{-}-\mathrm{N}$ and $\mathrm{NH}_{4}{ }^{+}-\mathrm{N}$ in pore water suggested that the proportion of $\mathrm{NH}_{4}{ }^{+}$consumed by sediment nitrification was much lower than the $\mathrm{NH}_{4}{ }^{+}$generated by mineralization under hypoxic conditions. Additionally, the significantly higher concentration of $\mathrm{NH}_{4}{ }^{+}-\mathrm{N}$ in pore water during the SP than that of the NSP $(p<0.05)$ indicated that the $\mathrm{NH}_{4}{ }^{+}$was mainly controlled by anaerobic mineralization. The seasonal differences in concentrations of $\mathrm{NH}_{4}{ }^{+}-\mathrm{N}$ and $\mathrm{NO}_{3}{ }^{-}-\mathrm{N}$ were mainly driven by DO level, since the oxygenated hypolimnetic water would promote the $\mathrm{NH}_{4}{ }^{+}$that originated from mineralization to be nitrified to $\mathrm{NO}_{3}{ }^{-}[5,14]$. Moreover, the seasonal differences in the vertical distribution of $\mathrm{NH}_{4}{ }^{+}$and $\mathrm{NO}_{3}{ }^{-}$in the upper layer $(0-19 \mathrm{~cm})$ and deep layers $(>19 \mathrm{~cm}$ ) (Figure 2) indicated that the effects of seasonal thermal stratification on $\mathrm{NH}_{4}{ }^{+}-\mathrm{N}$ in pore water only played a role in the upper layer (Figure 6). This might be related to the sediment porosity, which only permitted DO to permeate to some extent.
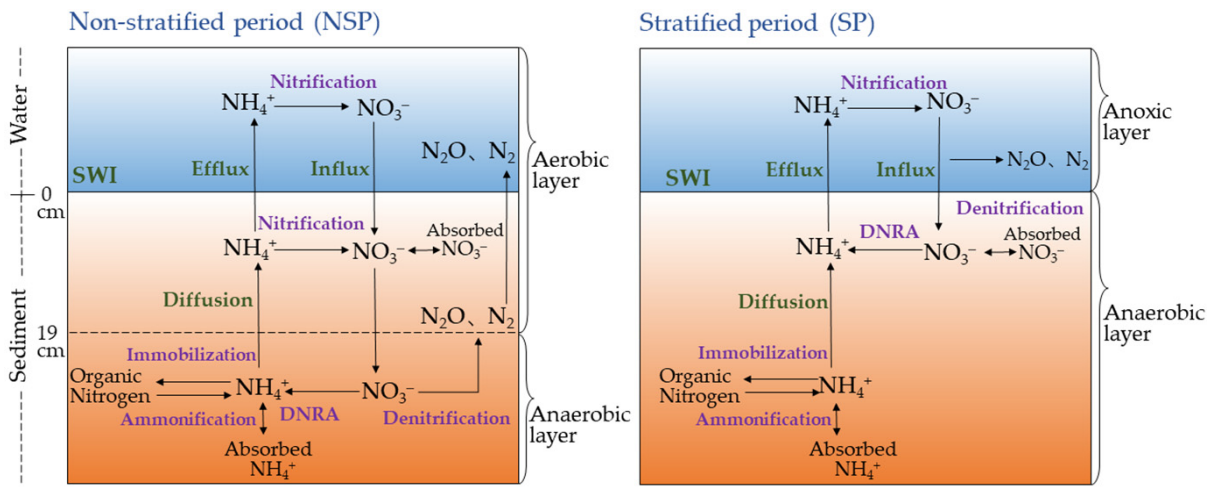

Figure 6. Schematic diagrams of major nitrogen biogeochemical processes at the SWI during the NSP and SP at the WJD reservoir. 
Previous studies have demonstrated that the concentrations of $\mathrm{NH}_{4}{ }^{+}-\mathrm{N}$ in the pore water of sediment are dominated by the content of organic matter, degradation rate, and deposition environment [6]. What is more, it has been verified that anaerobic mineralization is mainly affected by sediment properties (especially porosity) [35]. Additionally, a number of studies revealed that larger porosity in upper layers of the sediment would provide better conditions for various microorganism-driven nitrogen processes than that in deep layers, mainly resulting from better oxygen and nitrogen exchange among the SWI. Thus, it could be inferred that the concentration of $\mathrm{NH}_{4}{ }^{+}-\mathrm{N}$ decreased with depth in the upper layer in the SP, mainly owing to the different porosity between upper layers and deep layers by affecting the potential ammonification of organic matter in the two layers.

Subsequently, it has been reported that the dissimilatory nitrate reduction to ammonium (DNRA) could easily occur under the proper conditions with high carbon content and limited $\mathrm{NO}_{3}{ }^{-}$in the sediment $[9,36]$, which is consistent with the findings of this study in the WJD reservoir (carbon content reached 5.05\%, and the concentrations of $\mathrm{NO}_{3}{ }^{-}-\mathrm{N}$ were less than $0.31 \mathrm{mg} \cdot \mathrm{L}^{-1}$ ). Additionally, along with the $\mathrm{NO}_{3}{ }^{-}$decreasing in the upper layer in the NSP, the $\mathrm{NH}_{4}{ }^{+}$increased dramatically under hypoxic-anaerobic conditions (Figure 2), and the aerobic mineralization should not contribute so much newly produced $\mathrm{NH}_{4}{ }^{+}$. Thus, there might be a proportion of newly produced $\mathrm{NH}_{4}{ }^{+}$originating from DNAR. Overall, the shift of thermal stratification from the SP to the NSP not only contributed $\mathrm{NO}_{3}{ }^{-}$ in the SWI but also changed the nitrogen cycling processes of the sediment upper layer, i.e., the nitrogen transformation was jointly influenced by nitrification, mineralization, and DNAR in the NSP (Figure 6). Based on the discussion and findings mentioned above, we inferred the major nitrogen biogeochemical processes in the WJD reservoir by using schematic diagrams, as shown in Figure 6. In this study, different nitrogen biogeochemical processes were addressed in the SP and NSP, respectively. With that, we want to highlight the contribution of nitrification to the release of nitrogen at the SWI in the NSP since it will consequently influence nitrogen transportation in the downstream rivers, which will probably lead to uncertainty when evaluating the nitrogen budget in an impounded river.

\subsection{Contribution of Absorbed Nitrogen Species in Sediment Nitrogen Cycling}

Concentrations of adsorbed TN were significantly higher than those of water-soluble $\mathrm{TN}(p<0.05)$ in the SP and NSP, which was mainly attributed to the clay minerals in the sediment adsorbing a large amount of ionic nitrogen. Here, we employed the differences between water-soluble and absorbed $\mathrm{TN}(\Delta \mathrm{TN})$ to characterize the potential contribution and ability of absorbed nitrogen species in particulate matter to directly participate in the nitrogen transformation process (Figure 3). A clear seasonal variation in $\triangle \mathrm{TN}$ was observed (ANOVA, $\mathrm{N}=10, p=0.001$ ), especially in the upper layer $(0-10 \mathrm{~cm})$ of sediment. Compared with the constant variation in $\triangle \mathrm{TN}$ during the NSP, the increasing $\Delta \mathrm{TN}$ in the upper layer during the SP (Figure 3) suggested that it was more conducive for adsorbed nitrogen to participate in the conversion of water-soluble nitrogen in the SP. Furthermore, in the deep layers $(>10 \mathrm{~cm})$, the similar decreases and comparable concentrations of $\Delta \mathrm{TN}$, water soluble TN, and adsorbed TN between the two periods indicated that the adsorbed nitrogen contributed less to soluble TN than that in the upper layer and that the effects of thermal stratification on the transformation of adsorbed nitrogen was limited.

Specifically, the increases in $\Delta \mathrm{TN}$ and adsorbed TN in the upper layer during SP mainly resulted from the increases in dissolved organic nitrogen (DON), which was the major component of TN, displaying similar vertical profiles and seasonal variation as adsorbed TN (Figure 3). As a result, the significant seasonal differences in DON could account for those in adsorbed TN (Figure 4), which verified that the seasonal changes in adsorbed TN were primarily controlled by DON. Moreover, the water regulation of the reservoir would affect organic matter in sediment, e.g., anti-seasonal hydrological regime made it possible to continuously accumulate organic particulate matter from upstream to the sediment upper layer in the NSP, while the water discharge in the SP decreased the rate of particulate matter sedimentation, which resulted in an overall higher DON 
concentration in the NSP than that in the SP $(p<0.05)$. In addition, higher concentrations of $\mathrm{NH}_{4}{ }^{+}$in the sediment upper layer $(0-10 \mathrm{~cm}$ ) in pore water in the SP (Figure 2) and lower concentrations of absorbed DON than those in the NSP (Figure 3) were observed, which were driven by intensive mineralization in the sediment upper layer in the SP, demonstrating that the seasonal differences in mineralization rate were the dominant factor of DON. Furthermore, steady decreases in adsorbed DON in the upper layer $(0-10 \mathrm{~cm})$ (Figure 3), accompanied by an increase in $\mathrm{NH}_{4}{ }^{+}$in pore water in the SP (Figure 2) was mainly attributed to the vertical variation in the mineralization rate that generally would be decided by the porosity of the sediment [35]. Additionally, the inconspicuous differences in vertical distributions of absorbed inorganic nitrogen $\left(\mathrm{NH}_{4}{ }^{+}, \mathrm{NO}_{3}{ }^{-}\right)$during sampling time (Figure 3), compared with the significant seasonal variations in $\mathrm{NH}_{4}{ }^{+}$in sediment pore water, especially in sediment upper layer (Figure 2), demonstrate that these parts of nitrogen could not participate directly in the nitrogen transformation process. As noted above, the findings of this study revealed the complexity of the nitrogen species distribution and transformation in a thermally stratified reservoir, which is obviously different from natural lakes, and is something that should be emphasized in the future studies of the nitrogen budget and nitrogen management in reservoirs.

\subsection{Impact of Dam Construction on Sedimentary Nitrogen Sources}

The source of sediment organic matter and nitrogen transformation processes could be effectively characterized by the combination of $\delta^{15} \mathrm{~N}-\mathrm{PON}$ and the $\mathrm{C} / \mathrm{N}$ ratio $[37,38]$. According to the annual deposition rate $\left(0.46 \mathrm{~cm} \cdot \mathrm{a}^{-1}\right)$ [39] and the age of the WJD reservoir, we inferred that sedimentation after dam construction concentrated at the depth of 0-19 cm. The significant differences in sedimentation and nitrogen transformation processes of particulate matter before and after artificial dam construction are displayed by the $\mathrm{C} / \mathrm{N}$ ratio $(p<0.001)$ and $\delta^{15} \mathrm{~N}-\mathrm{PON}(p<0.05)$ (Table 5$)$, respectively. These remarkable differences in the $\mathrm{C} / \mathrm{N}$ ratio and $\delta^{15} \mathrm{~N}-\mathrm{PON}$ imply that dam construction severely alters particulate matter deposition in a reservoir, suggesting that it would be important to reassess the effects of dams and reservoirs on nitrogen accumulation and transportation in impounded rivers.

Table 5. Statistics of $\mathrm{C} / \mathrm{N}$ ratio and $\delta^{15} \mathrm{~N}-\mathrm{PON}$ at different sampling periods.

\begin{tabular}{ccccc}
\hline Sampling Time & Items & $\begin{array}{c}\text { Before } \\
\text { Construction }\end{array}$ & $\begin{array}{c}\text { After } \\
\text { Construction }\end{array}$ & $\boldsymbol{t}$-Test \\
\hline \multirow{2}{*}{ January 2018 } & C/N ratio & $11.11 \pm 1.68$ & $8.99 \pm 0.51$ & $5.09 * * *$ \\
& $\delta^{15}$ N-PON & $6.29 \pm 0.35$ & $6.22 \pm 0.21$ & 0.62 \\
\hline \multirow{2}{*}{ July 2019 } & C/N ratio & $11.72 \pm 0.97$ & $9.45 \pm 0.74$ & $8.09^{* * *}$ \\
& $\delta^{15}$ N-PON & $5.46 \pm 0.31$ & $5.81 \pm 0.62$ & $-2.23^{*}$ \\
\hline
\end{tabular}

Note: ${ }^{* * *}$ was $p<0.001 ;{ }^{*}$ was $p<0.05$.

A large isotope fractionation $(+4.9 \sim+7.2 \%$ ) was observed at $0-19 \mathrm{~cm}$ in the SP. Generally, the different isotopic fractionation among nitrogen cycling processes would verify the values of isotopic signals [21], e.g., the isotope fractionation caused by degradation was about $1 \%$. Hence, this large isotope fractionation in the SP could be attributed to the mineralization rate under anaerobic conditions. Additionally, the vertical profiles of $\delta^{15} \mathrm{~N}-\mathrm{PON}$ displayed a significant seasonal change at 0-19 $\mathrm{cm}$, and it decreased with depth in the SP, while not expressing clear variation in the NSP (Figure 5). Nitrogen isotope fractionation during mineralization leading to ${ }^{15} \mathrm{~N}$ enriched in the residual of mineralization (PON) would consequently result in the enrichment of ${ }^{15} \mathrm{~N}$ in organic particulate matter at the sediment upper layer. Furthermore, accompanied by an incompatible exponential decay model of depth and the content of organic nitrogen $\left(R^{2}<0.5\right)$ [35], it was commonly verified that the nitrogen transformation processes were mainly dominated by mineralization at the sediment upper layer under anaerobic conditions.

Lower $\mathrm{C} / \mathrm{N}$ ratio values were noticed at the sediment upper layer than at the bottom (Figure 5), which could be attributed to DO and microbial activity playing key roles at the 
sediment upper layer as the major factors for the degradation process of organic matter [40]. Moreover, the vertical distribution of the $\mathrm{C} / \mathrm{N}$ ratio was displayed analogically in the SP and NSP (Figure 5). On account of the $\mathrm{C}$ and $\mathrm{N}$ in the degradation processes displaying an equal proportion, which was related to Formulas (7) and (8) [41], the degradation reactions could be considered as a potential factor driving the vertical distribution of the $\mathrm{C} / \mathrm{N}$ ratio.

$$
\begin{aligned}
\left(\mathrm{CH}_{2} \mathrm{O}\right)_{106}\left(\mathrm{NH}_{3}\right)_{16}\left(\mathrm{H}_{3} \mathrm{PO}_{4}\right)+138 \mathrm{O}_{2} & \rightarrow 106 \mathrm{CO}_{2}+16 \mathrm{HNO}_{3}+\mathrm{H}_{3} \mathrm{PO}_{4}+122 \mathrm{H}_{2} \mathrm{O} \\
\left(\mathrm{CH}_{2} \mathrm{O}\right)_{106}\left(\mathrm{NH}_{3}\right)_{16}\left(\mathrm{H}_{3} \mathrm{PO}_{4}\right)+94.4 \mathrm{HNO}_{3} & \rightarrow 106 \mathrm{CO}_{2}+55.2 \mathrm{~N}_{2}+\mathrm{H}_{3} \mathrm{PO}_{4}+177.2 \mathrm{H}_{2} \mathrm{O}
\end{aligned}
$$

\subsection{Endogenous Release of Sediment Nitrogen}

Diffusive fluxes of inorganic nitrogen were different depending on seasonal changes, i.e., the diffusion flux (efflux) of $\mathrm{NH}_{4}{ }^{+}-\mathrm{N}$ was 1.65 times in the SP than that in the NSP (Table 4), which was mainly attributed to the concentration gradient and microbial activity verified by the finding that the release of $\mathrm{NH}_{4}{ }^{+}-\mathrm{N}$ was significantly increased when nitrification was restricted. The concentrations of $\mathrm{NH}_{4}{ }^{+}$at the SWI in the SP were 5.3 times than those in the NSP, which would mainly be governed by the thermal stratification, the seasonal changes of mineralization rate, and the water density in the deep reservoir [5,14], resulting in a stagnation of $\mathrm{NH}_{4}{ }^{+}$in pore water and a higher nitrogen gradient during the SP. The diffusion fluxes of $\mathrm{NO}_{3}{ }^{-}$were presented as influxes from water towards the sediment, i.e., the $\mathrm{NO}_{3}{ }^{-}$was accumulated in the sediment in both the SP and NSP, which was mainly due to sufficient denitrification under anaerobic conditions, which significantly reduced the concentration gradient of $\mathrm{NO}_{3}{ }^{-}$. Compared with other reservoirs/lakes worldwide, the diffusion fluxes of $\mathrm{NH}_{4}{ }^{+}-\mathrm{N}$ at the SWI of the WJD reservoir were higher than those in Marano and Grado Lagoon in Italy, Danjiangkou Reservoir, Suma Park Reservoir, and Guanting Reservoir, which were less polluted, while the diffusion fluxes were closer to those at in the Yuqiao Reservoir, Upper Klamath Lake, and Erhai Lake (Table 6). This demonstrated that deep canyon reservoirs in Southwest China have relatively high $\mathrm{NH}_{4}{ }^{+}$ effluxes from the SWI, even though this region has been generally considered as a less disturbed and contaminated area, which implies that further studies are needed to assess the potential nitrogen pollution that can attributed to endogenous nitrogen release.

\begin{tabular}{|c|c|c|c|c|}
\hline \multirow{2}{*}{ Study Site } & \multirow{2}{*}{ Location } & \multicolumn{2}{|c|}{ Diffusion Flux $\left(\mathrm{mg} \cdot \mathrm{m}^{-2} \cdot \mathrm{d}^{-1}\right)$} & \multirow{2}{*}{ Reference } \\
\hline & & $\mathrm{NH}_{4}{ }^{+}-\mathrm{N}$ & $\mathrm{NO}_{3}{ }^{-}-\mathrm{N}$ & \\
\hline WJD Reservoir & China & $9.48 \sim 15.66$ & $-1.49 \sim-0.21$ & This study \\
\hline Danjiangkou Reservoir & China & $0.39 \sim 17.66$ & $-16.97 \sim-4.33$ & [42] \\
\hline Yuqiao Reservoir & China & $4.38 \sim 30.57$ & $-31.96 \sim-4.13$ & [43] \\
\hline Guanting Reservoir & China & $1.59 \sim 13.00$ & - & [6] \\
\hline Erhai Lake & China & $8.97 \sim 74.84$ & - & [32] \\
\hline Suma Park Reservoir & Australia & $1.70 \pm 1.20$ & $0.30 \pm 0.20$ & [20] \\
\hline Marano and Grado Lagoon & Italy & $4.88 \pm 0.76$ & $-21.30 \pm 3.45$ & [44] \\
\hline Upper Klamath Lake & America & $4 \sim 134$ & $-20 \sim-0.1$ & [45] \\
\hline
\end{tabular}

Table 6. Comparison of inorganic nitrogen diffusion fluxes at the SWI of other reservoirs.

Note: "-" was no data.

Yu et al. [46] investigated the sediment characteristics (including the sediment thickness and the concentrations of TN) of different sampling sites in the Dongfeng reservoir, a canyon reservoir along the same river as the one in this study, and they reported that although the sediment thickness varied spatially, the concentrations of TN in the surface sediment throughout the reservoir varied within a small range. Based on the updated study at the WJD reservoir [47] - and provided that the mean slope of hills was $30^{\circ}$ and the mean depth was $90 \mathrm{~m}$ - the area of the surface sediment was estimated to be $11.6 \mathrm{~km}^{2}$, and the total content of $\mathrm{NH}_{4}{ }^{+}$in the water of the WJD reservoir reached $244 \mathrm{t}$. Thus, the total annual release of $\mathrm{NH}_{4}{ }^{+}$was calculated to be $53.4 \mathrm{t}$, accounting for $21.8 \%$ of the total $\mathrm{NH}_{4}{ }^{+}$ content in the water of the WJD reservoir, which highlights the contribution of diffused 
$\mathrm{NH}_{4}{ }^{+}$from sediment to overlying water and the need for more attention in a future study to the evaluation of the environmental effects of endogenous nitrogen release in a high nitrogen-loading river basin.

\section{Conclusions}

This work aimed to identify the nitrogen transformation processes affected by ambient conditions of seasonal thermal stratification, to explore the factors controlling endogenous nitrogen release, and to quantify the nitrogen diffusion fluxes at the SWI of the WJD reservoir, an artificial deep reservoir in the Southeast Asian Karst Region. The vertical distribution profiles of nitrogen species verified that the mineralization rate of the upper layer $(0-10 \mathrm{~cm})$ overpassed that of bottom in the SP. Additionally, the nitrification that occurred in NSP illustrated the existence of $\mathrm{NO}_{3}{ }^{-}$at $0-19 \mathrm{~cm}$ in pore water. Even though similar phenomena have been observed in other lakes worldwide, the findings were seldom explained and reported in deep canyon reservoirs in Southwest China. We inferred that if thermal stratification commonly affected the nitrogen processes in most of the similar reservoirs, then the total $\mathrm{NO}_{3}{ }^{-}$influxes in deep reservoirs could be re-evaluated for a complete understanding of the nitrogen budget in impounded rivers worldwide. Combined with the seasonal distribution of $\delta^{15} \mathrm{~N}-\mathrm{PON}$ and the $\mathrm{C} / \mathrm{N}$ ratio, we also observed that the large isotope fractionation and significant seasonal differences in nitrogen species in the upper layer during the SP were mainly controlled by mineralization. Moreover, the sediment served as the source of $\mathrm{NH}_{4}{ }^{+}-\mathrm{N}$ and the reduction in $\mathrm{NO}_{3}{ }^{-}-\mathrm{N}$ during the sampling time and the diffusion fluxes of sediment nitrogen were relatively close to those of seriously polluted lakes in China, which suggests that the deep canyon reservoirs may have an endogenous nitrogen transportation that is similar to that in polluted lakes, and that it may be enlarged by the water storage regulation mode that is used for better power generation. This study emphasized the influence of ambient conditions on endogenous nitrogen transformation and diffusion in a deep reservoir and provides an efficiently theoretical basis for managing watershed-scale nitrogen contamination in aquatic systems.

Author Contributions: Y.H.: methodology, writing—original draft preparation, and software; X.L.: conceptualization, investigation, data analysis, and manuscript editing; S.C.: sample collection, methodology, and investigation; J.R.: experimental investigation and sample collection; L.B.: data analysis and manuscript editing; J.L.: methodology and investigation; Y.G. and L.W.: sample collection and experimental investigation. All authors have read and agreed to the published version of the manuscript.

Funding: This research was funded by the National Natural Science Foundation of China (Grant Nos. 41661144029, 41672351) and the Natural Science Foundation of Tianjin City (18JCYBJC91000).

Institutional Review Board Statement: Not applicable.

Informed Consent Statement: Not applicable.

Data Availability Statement: The datasets used or analyzed during the current study are available from the corresponding author on reasonable request.

Conflicts of Interest: The authors declare no conflict of interest.

\section{References}

1. Green, P.A.; Vorosmarty, C.J.; Meybeck, M.; Galloway, J.N.; Peterson, B.J.; Boyer, E.W. Pre-industrial and contemporary fluxes of nitrogen through rivers: A global assessment based on typology. Biogeochemistry 2004, 68, 71-105. [CrossRef]

2. Valiela, I.; Geist, M.; McClelland, J.; Tomasky, G. Nitrogen loading from watersheds to estuaries: Verification of the waquoit bay nitrogen loading model. Biogeochemistry 2000, 49, 277-293. [CrossRef]

3. Zhang, Y.Q.; Wu, Z.H.; Xu, M.Y.; Pei, Z.L.; Lu, X.; Zhang, D.C.; Wu, T.; Li, B.; Xu, S.J. Nutrient deposition over the past 60 years in a reservoir within a medium-sized agricultural catchment. Sci. Total Environ. 2021, 764, 142896. [CrossRef]

4. Zeng, J.; Han, G.L. Tracing zinc sources with zn isotope of fluvial suspended particulate matter in Zhujiang river, Southwest China. Ecol. Indic. 2020, 118, 106723. [CrossRef]

5. Liu, X.L.; Liu, C.Q.; Li, S.L.; Wang, F.S.; Wang, B.L.; Wang, Z.L. Spatiotemporal variations of nitrous oxide $\left(\mathrm{N}_{2} \mathrm{O}\right)$ emissions from two reservoirs in SW China. Atmos. Environ. 2011, 45, 5458-5468. [CrossRef] 
6. Lei, P.; Zhu, J.J.; Zhong, H.; Pan, K.; Zhang, L.; Zhang, H. Distribution of nitrogen and phosphorus in pore water profiles and estimation of their diffusive fluxes and annual loads in guanting reservoir (Gtr), Northern China. Bull. Environ. Contam. Toxicol. 2021, 106, 10-17. [CrossRef] [PubMed]

7. Zhu, Y.Y.; Tang, W.Z.; Jin, X.; Shan, B.Q. Using biochar capping to reduce nitrogen release from sediments in eutrophic lakes. Sci. Total Environ. 2019, 646, 93-104. [CrossRef]

8. Aalto, S.L.; Saarenheimo, J.; Ropponen, J.; Juntunen, J.; Rissanen, A.J.; Tiirola, M. Sediment diffusion method improves wastewater nitrogen removal in the receiving lake sediments. Water Res. 2018, 138, 312-322. [CrossRef] [PubMed]

9. Hardison, A.K.; Algar, C.K.; Giblin, A.E.; Rich, J.J. Influence of organic carbon and nitrate loading on partitioning between dissimilatory nitrate reduction to ammonium (Dnra) and $\mathrm{N}_{2}$ production. Geochim. Et Cosmochim. Acta 2015, 164, 146-160. [CrossRef]

10. Zarfl, C.; Lumsdon, A.E.; Berlekamp, J.; Tydecks, L.; Tockner, K. A global boom in hydropower dam construction. Aquat. Sci. 2015, 77, 161-170. [CrossRef]

11. Zeng, J.; Han, G.L.; Yang, K.H. Assessment and sources of heavy metals in suspended particulate matter in a tropical catchment, Northeast Thailand. J. Clean. Prod. 2020, 265, 10. [CrossRef]

12. Mulligan, M.V.; Soesbergen, A.; Saenz, L. GOODD, a global dataset of more than 38,000 georeferenced dams. Sci. Data 2020, 7, 1-8. [CrossRef]

13. Winton, R.S.; Calamita, E.; Wehrli, B. Reviews and syntheses: Dams, water quality and tropical reservoir stratification. Biogeosciences 2019, 16, 1657-1671. [CrossRef]

14. Dadi, T.; Rinke, K.; Friese, K. Trajectories of sediment-water interactions in reservoirs as a result of temperature and oxygen conditions. Water 2020, 12, 19. [CrossRef]

15. Muller, S.; Mitrovic, S.M.; Baldwin, D.S. Oxygen and dissolved organic carbon control release of $n$, $p$ and fe from the sediments of a shallow, polymictic lake. J. Soils Sediments 2016, 16, 1109-1120. [CrossRef]

16. Liikanen, A.; Murtoniemi, T.; Tanskanen, H.; Vaisanen, T.; Martikainen, P.J. Effects of temperature and oxygen availability on greenhouse gas and nutrient dynamics in sediment of a eutrophic mid-boreal lake. Biogeochemistry 2002, 59, 269-286. [CrossRef]

17. Cai, Y.Y.; Cao, Y.J.; Tang, C.Y. Evidence for the primary role of phytoplankton on nitrogen cycle in a subtropical reservoir: Reflected by the stable isotope ratios of particulate nitrogen and total dissolved nitrogen. Front. Microbiol. 2019, 10, 2202. [CrossRef]

18. Ozkundakci, D.; Hamilton, D.P.; Gibbs, M.M. Hypolimnetic phosphorus and nitrogen dynamics in a small, eutrophic lake with a seasonally anoxic hypolimnion. Hydrobiologia 2011, 661, 5-20. [CrossRef]

19. Lavery, P.S.; Oldham, C.E.; Ghisalberti, M. The use of fick's first law for predicting porewater nutrient fluxes under diffusive conditions. Hydrol. Process. 2001, 15, 2435-2451. [CrossRef]

20. Chowdhury, M.; Al Bakri, D. Diffusive nutrient flux at the sediment-water interface in suma park reservoir, Australia. Hydrol. Sci. J. 2006, 51, 144-156. [CrossRef]

21. Liu, X.L.; Han, G.L.; Zeng, J.; Liu, M.; Li, X.Q.; Boeckx, P. Identifying the sources of nitrate contamination using a combined dual isotope, chemical and bayesian model approach in a tropical agricultural river: Case study in the mun river, Thailand. Sci. Total Environ. 2021, 760, 143938. [CrossRef]

22. Han, G.L.; Tang, Y.; Liu, M.; Van Zwieten, L.; Yang, X.M.; Yu, C.X.; Wang, H.L.; Song, Z.L. Carbon-nitrogen isotope coupling of soil organic matter in a karst region under land use change, Southwest China. Agric. Ecosyst. Environ. 2020, 301, 11. [CrossRef]

23. Zeng, J.; Yue, F.J.; Li, S.L.; Wang, Z.J.; Qin, C.Q.; Wu, Q.X.; Xu, S. Agriculture driven nitrogen wet deposition in a karst catchment in Southwest China. Agric. Ecosyst. Environ. 2020, 294, 10. [CrossRef]

24. Han, G.L.; Liu, C.Q. Water geochemistry controlled by carbonate dissolution: A study of the river waters draining karst-dominated terrain, Guizhou province, China. Chem. Geol. 2004, 204, 1-21. [CrossRef]

25. Zeng, J.; Han, G.L. Preliminary copper isotope study on particulate matter in Zhujiang river, Southwest China: Application for source identification. Ecotoxicol. Environ. Saf. 2020, 198, 8. [CrossRef] [PubMed]

26. Yin, R.; Wang, F.S.; Mei, Y.H.; Yao, C.Q.; Go, M.Y. Distribution of phosphorus forms in the sediments of cascade reservoir with different trophic states in Wujiang catchment. Chin. J. Ecol. 2010, 29, 91-97, (In Chinese with English Abstract).

27. Liu, X.L. Effects of Cascade Reservoirs Development on the Nitrogen Biogeochemical Processes in the Watershed-A Case Study of the Main Stream and Tributary in the Middle and Upper Reaches of the Wujiang River, Maotiao River. Ph.D. Thesis, Institute of Geochemistry, Chinese Academy of Science, Guiyang, China, 2010.

28. Hogarh, J.N.; Adu-Gyamfi, E.; Nukpezah, D.; Akoto, O.; Adu-Kumi, S. Contamination from mercury and other heavy metals in a mining district in Ghana: Discerning recent trends from sediment core analysis. Environ. Syst. Res. 2016, 5, 1-9. [CrossRef]

29. Lockhart, W.L.; Macdonald, R.W.; Outridge, P.M.; Wilkinson, P.; DeLaronde, J.B.; Rudd, J.W.M. Tests of the fidelity of lake sediment core records of mercury deposition to known histories of mercury contamination. Sci. Total Environ. 2000, 260, 171-180. [CrossRef]

30. Barra, R.; Cisternas, M.; Urrutia, R.; Pozo, K.; Pacheco, P.; Parra, O.; Focardi, S. First report on chlorinated pesticide deposition in a sediment core from a small lake in central chile. Chemosphere 2001, 45, 749-757. [CrossRef]

31. Copetti, D.; Tartari, G.; Valsecchi, L.; Salerno, F.; Viviano, G.; Mastroianni, D.; Yin, H.B.; Vigano, L. Phosphorus content in a deep river sediment core as a tracer of long-term (1962-2011) anthropogenic impacts: A lesson from the Milan metropolitan area. Sci. Total Environ. 2019, 646, 37-48. [CrossRef] 
32. Zhao, H.C.; Zhang, L.; Wang, S.R.; Jiao, L.X. Features and influencing factors of nitrogen and phosphorus diffusive fluxes at the sediment-water interface of Erhai lake. Environ. Sci. Pollut. Res. 2018, 25, 1933-1942. [CrossRef]

33. Krom, M.D.; Berner, R.A. The diffusion coefficients of sulphate, ammonium and phosphate in anoxic marine sediments. Limnol. Oceanogr 1980, 25, 327-337. [CrossRef]

34. Ni, Z.X.; Zhang, L.; Yu, S.; Jiang, Z.J.; Zhang, J.P.; Wu, Y.C.; Zhao, C.Y.; Liu, S.L.; Zhou, C.H.; Huang, X.P. The porewater nutrient and heavy metal characteristics in sediment cores and their benthic fluxes in daya bay, South China. Mar. Pollut. Bull. 2017, 124, 547-554. [CrossRef]

35. Toussaint, E.; De Borger, E.; Braeckman, U.; De Backer, A.; Soetaert, K.; Vanaverbeke, J. Faunal and environmental drivers of carbon and nitrogen cycling along a permeability gradient in shallow North sea sediments. Sci. Total Environ. 2021, 767, 144994. [CrossRef] [PubMed]

36. Kraft, B.; Tegetmeyer, H.E.; Sharma, R.; Klotz, M.G.; Ferdelman, T.G.; Hettich, R.L.; Geelhoed, J.S.; Strous, M. The environmental controls that govern the end product of bacterial nitrate respiration. Science 2014, 345, 676-679. [CrossRef]

37. Liu, X.L.; Li, S.L.; Wang, Z.L.; Wang, B.L.; Han, G.L.; Wang, F.S.; Bai, L.; Xiao, M.; Yue, F.J.; Liu, C.Q. Sources and key processes controlling particulate organic nitrogen in impounded river-reservoir system on the Maotiao river, Southwest China. Inland Waters 2018, 8, 167-175. [CrossRef]

38. Liu, J.K.; Han, G.L. Tracing riverine particulate black carbon sources in Xijiang River Basin: Insight from stable isotopic composition and bayesian mixing model. Water Res. 2021, 194, 8. [CrossRef]

39. Yang, Y.X.; Xiang, P.; Lu, W.Q.; Wang, S.L. The sediment rate and burial fluxes of carbon and nitrogen in Wujiangdu reservoir, Guizhou, China. Earth Environ. 2017, 45, 66-73. (In Chinese with English Abstract)

40. Arndt, S.; Jorgensen, B.B.; LaRowe, D.E.; Middelburg, J.J.; Pancost, R.D.; Regnier, P. Quantifying the degradation of organic matter in marine sediments: A review and synthesis. Earth-Sci. Rev. 2013, 123, 53-86. [CrossRef]

41. Xiao, H.Y. Nitrogen Biogeochemical Cycles in a Seasonally Anoxic Lake. Ph.D. Thesis, Institute of Geochemistry, Chinese Academy of Science, Guiyang, China, 2002.

42. Wang, H.; Han, Y.P.; Pan, L.D. Spatial-temporal variation of nitrogen and diffusion flux across the water-sediment interface at the hydro-fluctuation belt of Danjiangkou reservoir in China. Water Supply 2020, 20, 1241-1252. [CrossRef]

43. Wen, S.L.; Wu, T.; Yang, J.; Jiang, X.; Zhong, J.C. Spatio-temporal variation in nutrient profiles and exchange fluxes at the sediment-water interface in Yuqiao reservoir, China. Int. J. Environ. Res. Public Health 2019, 16, 16. [CrossRef]

44. De Vittor, C.; Faganeli, J.; Emili, A.; Covelli, S.; Predonzani, S.; Acquavita, A. Benthic fluxes of oxygen, carbon and nutrients in the Marano and Grado lagoon (Northern Adriatic Sea, Italy). Estuar. Coast. Shelf Sci. 2012, 113, 57-70. [CrossRef]

45. Kuwabara, J.S.; Topping, B.R.; Lynch, D.D.; Carter, J.L.; Essaid, H.I. Benthic nutrient sources to hypereutrophic upper Klamath Lake, Oregon, USA. Environ. Toxicol. Chem. 2009, 28, 516-524. [CrossRef] [PubMed]

46. Yu, N.; Qin, Y.; Hao, F.; Lang, Y.; Wang, F. Using seismic surveys to investigate sediment distribution and to estimate burial fluxes of OC, N, and $\mathrm{P}$ in a Canyon reservoir. Acta Geochim. 2019, 38, 785-795. [CrossRef]

47. Chen, S.N.; Yue, F.J.; Liu, X.L.; Zhong, J.; Yi, Y.B.; Wang, W.F.; Qi, Y.L.; Xiao, H.Y.; Li, S.L. Seasonal variation of nitrogen biogeochemical processes constrained by nitrate dual isotopes in cascade reservoirs, Southwestern China. Environ. Sci. Pollut. Res. 2021, 28, 26617-26627. [CrossRef] 